\title{
SEROLOGIES USE IN THE IDENTIFICATION OF INSECTS PREDATORS PREY
}

\author{
ANA CAROLINA MACIEL REDOAN ${ }^{1}$, \\ CARLOS ROBERTO SOUSA-SILVA ${ }^{1}$ and IVAN CRUZ ${ }^{2}$
}

\begin{abstract}
IUniversidade Federal de São Carlos, São Carlos, SP, Brasil,ac.redoan@gmail.com,dcrs@ufscar.br; ${ }^{2}$ Embrapa Milho e Sorgo, Sete Lagoas, MG, Brasil, ivan.cruz@embrapa.br
\end{abstract}

Revista Brasileira de Milho e Sorgo, v.15, n.2, p. 157-170, 2016

\begin{abstract}
This study aimed to produce antiserum for the main pests found in maize, Spodoptera frugiperda, Helicoverpa zea and armigera, Rhopalosiphum maidis, and uses it to determine their predators. Pest samples were macerated in $0.85 \%$ saline solution. The macerated were centrifuged and the supernatants were used as immunizing antigens to obtain the antiserum. For this purpose, a rabbit was immunized with $3.0 \mathrm{ml}$ of the immunizing antigen on the lymph node region. Homologous serological tests were performed by double diffusion in agar. The homologous serological reactions were positive after seven days of antigen inoculation. The technique has sensitivity to detect predation of the pests studied. The tests were positive for a prey in the digestive tract of the predator to 96 hours of ingestion. Regarding the number of prey ingested there was no difference in the lines. It is concluded that after a single injection of antigen in rabbit lymph node region, it was possible to get an antiserum specific for pests of corn. Field tests showed that there was a certain food preference of Doru luteipes by S. frugiperda, Chrysoperla externa by aphid.
\end{abstract} Key words: Zea mays, antigens, antiserum, predation.

\section{UTILIZAÇÃO DA SEROLOGIA NA IDENTIFICAÇÃO DE FONTE DE ALIMENTO POR INSETOS PREDADORES}

\begin{abstract}
RESUMO - O presente trabalho teve como objetivo produzir antissoros para as principais pragas encontradas na cultura do milho Spodoptera frugiperda, Helicoverpa armigera e zea e Rhopalosiphum maidis e sua utilização na determinação de seus predadores. Amostras das pragas foram maceradas em presença de solução salina $0,85 \%$. Os macerados foram centrifugados e os sobrenadantes utilizados como antígenos imunizantes para obtenção do antissoro. Para esse propósito, um coelho foi imunizado com 3,0 $\mathrm{mL}$ do antígeno imunizante na região próxima do linfonódulo. Testes serológicos homólogos foram realizados em dupla difusão em ágar. Reações serológicas homólogas foram positivas logo após sete dias da inoculação do antígeno. A técnica tem sensibilidade para detectar predação das pragas estudadas neste trabalho. Os testes foram positivos para uma presa no trato digestivo do predador até $96 \mathrm{~h}$ de sua ingestão. Com relação ao número de presas ingeridas, não houve diferença nas linhas. Concluiu-se que, após uma única injeção do antígeno na região do linfonódulo do coelho, foi possível obter-se antissoro específico para as pragas do milho, em que os testes de campo mostram que houve uma certa preferência alimentar de Doru luteipes por $S$. frugiperda, Chrysoperla externa por pulgão.
\end{abstract}

Palavras-chave: Zea mays, antígenos, antissoro, predação. 
Maize (Zea mays L.) is grown in almost all Brazilian territory with grain production of 206.34 million tons in 2014/2015 crop season which represents an increase of $6.6 \%$ compared to the previous season with 193.62 million tons of grain (Conab, 2015). This high production however, could be higher if pest incidence and severity was lower (Figueiredo et al., 2006). Currently, Spodoptera frugiperda (Smith, 1797), Helicoverpa armigera (Hübner, 1805), H. zea (Boddie, 1850) (Lepidoptera: Noctuidae) and aphid Rhopalosiphum maidis (Fitch, 1856) (Homoptera: Aphididae) are species causing greater economic impact in the production of grain corn in Brazil (Cruz et al., 2007; Czepak et al., 2013.). Responsible for consuming much of the area of corn leaves, the fall armyworm $S$. frugiperda can reduce 17 to $54.49 \%$ of grain yield by causing severe injuries to plant in all development stages (Figueiredo et al., 2006). Nevertheless, when the injury occurs in seedling usually the plant dies with a reduction in the expected number of plants at harvest. The larva also feeds the stem; peduncle and grains developing in the ear, causing direct damage to production (Cruz, 2008a).

The corn earworm $H$. zea also feeds and cause significant damage to the grain still in development (Rodriguez-del-Bosque et al., 2012). In addition to direct losses, the insect may also before reach the inside of the corncob cause indirect damage to sectioning styles-stigma, causing abortion of the flower. More recently, $H$. armigera, until then a quarantine pest for Brazil, may also be found sharing habitat with H. zea (Czepak et al., 2013). This insect pest caused losses estimated to $\$ 2$ billion in the last two seasons of maize production with average incidence reported up to $96 \%$ infestation in the ear. This was due to ability to attack large numbers of hosts and to cause damage to the reproductive parts of the crops (Czepak et al., 2013).
Although grain yield loss due to the caterpillar attack are those that cause the most economic damage to farmers in recent years these same corn farmers have been surprised by the high infestation of $R$. maidis (corn aphid). High infestations may have been triggered mainly by the drought that prevails in recent years, which coupled with high temperatures benefits the rapid development and spread of this insect (Cruz et al., 2012).

In an attempt to avoid the losses caused by insect pests, there is an excessive increase and inappropriate use of chemicals on agricultural areas causing negative environmental impacts. Therefore, researchers and farmers have sought biological control as an alternative to environmental and economic sustainability (Cruz, 2002, 2008b, 2008c, 2008d, 2009, 2015; Cruz et al., 2009, 2016). According to Cruz (2008a), the natural control agents with great potential to reduce the population of corn pest are those with high voracity and mobility to find the prey. Among them, the earwigs: Doru luteipes (Scudder, 1876) (Dermaptera: Forficulidae) and Euborellia annulipes (Lucas, 1847) (Dermaptera: Anisolabididae), ladybugs such as Coleomegilla maculata (De Geer, 1775) and Olla v-nigrum (Mulsant, 1866) (Coleoptera: Chrysopidae), and the green lacewing Chrysoperla externa (Hagen, 1861) (Neuroptera: Chrysopidae).

Due to the difficulties for visual observation of predation on the field level, the application of methods for the secure identification of these natural controllers must be investigated. Serology is a technique widely used by many researchers to determine predators and is based on antigen / antibody type reactions. Antibodies are obtained for the pest to be investigated and antigens obtained from the various prey used as a food source. Antigens and antibodies diffuse into agar 
gel and react to form precipitation lines. This highly sensitive and specific technique has some advantages: convenience, simplicity and precision to the knowledge of these relationships (Pettersson, 1972).

Through specific reactions makes it possible for us to identify what is the predator's diet in their natural environment. Once a good natural enemy is identified, it can be used without risk of having cases of resistance as occurs with the use of pesticides (Bueno, 2000). Thus the present study aimed to produce antiserum for the main pests found in corn, as $S$. frugiperda, $H$. armigera, $H$. zea and $R$. maidis and thus determine whether such prey are actually preferred for some of its main predators.

\section{Material and Methods}

The experiments were conducted at Brazilian Agricultural Research Corporation (Embrapa Maize and Sorghum), Sete Lagoas, Minas Gerais, Brazil., Larvae from $S$. frugiperda, $H$. zea, $H$. armigera and adult/ninph of the aphid $R$. maidis were used as prey in the preparation of antisera that were later used in serological test homologous and heterologous against possible predators.

\section{Production of immunizing antigens (Ag) anti serum (As):}

In obtaining the respective immunizing antigens, three fourth instar larvae were used of each species, S. frugiperda (AgSf), H. armigera (Agha) and $H$. zea $(\mathrm{AgHz})$ and nymphs and adults of corn aphid, $R$. maidis (AgRm). Caterpillars and aphids were left without food for 24 hours; subsequently each specific assembly was steeped separately in saline $(0.85 \%)$ and centrifuged at $6000 \mathrm{~g}$ for 10 minutes.
The supernatants, emulsified with complete Freund Adjuvant (v/v), were used as immunizing antigens for obtaining the various antisera (As) for the selected corn pests. For the production of each antiserum, rabbits of the New Zealand breed of $5 \mathrm{~kg}$ and one year of age were used. Each rabbit was immunized by inoculation of $3.0 \mathrm{ml}$ of the immunizing antigen (AgSf Agha, AgHz or AgRm) in the node region of its rear leg (Olive, 1975). Before the first inoculation a blood sample was taken to be used as control (C) in serologic reactions. After inoculation, daily bleedings were performed on each rabbit for 30 days, for the withdrawal of antisera. The bleeds $(10 \mathrm{ml})$ were made by means of longitudinal cuts in the marginal vein of the rabbit ear and the collected blood was initially kept at rest for two hours at room temperature $\left(23^{\circ}\right.$ C) and then in a refrigerator $\left(4^{\circ} \mathrm{C}\right)$ for 24 hours. The clot was discarded and the supernatant corresponding to each pest species $S$. frugiperda (AsSf), H. armigera (AsHa), H. zea (AsHz) and aphid R. maidis (AsRm) was stored in a freezer at $-2{ }^{\circ} \mathrm{C}$ for the determination of their respective titles and use in serological tests.

Serologic tests: serological tests were conducted using the double diffusion in agar at $1 \%$, containing $0.02 \%$ sodium azide, $0.85 \%$ sodium chloride, $2 \%$ of magnesium chloride and $0,5 \mathrm{ml}$ of a solution of $1 \%$ trypan blue on microscope slides (3.0 $\mathrm{ml}$ agar solution per slide, $75 \mathrm{~mm}$ x $25 \mathrm{~mm}$ ) according to the methodology described by Schaad et al. (1990).

\section{Homologous serological tests:}

Antisera obtained in each performed bloodletting were tested against their homologous antigens. We observed the initial onset of precipitation lines and the number of such lines in 
different reactions. The antisera, which allowed larger numbers of lines, were titrated. It was also evaluated the reactions of each of the antisera to the different stages and / or instars of their homologous antigens. That is, eggs, small caterpillars (1st instar), average caterpillar (2nd to 3rd instar), large caterpillars (4th to 5 th instar) or pupae of $S$. frugiperda, $H$. zea and $H$. armigera, and nymphs and adults of aphid $R$. maidis, macerated in saline $0.85 \%$.

\section{Titration of the antiserum:}

The titles of the respective antisera $\operatorname{AsSf}(S$. frugiperda), AsHa (H. armigera), $\mathrm{AsHz}(H$. zea) and AsRm ( $R$. maidis) were determined using their fractions diluted in $\mathrm{NaCl}$ solution $0.85 \%$ in a geometric progression of reason 2 in serological reactions with their homologous antigens. The antisera that provided the greatest number of precipitin lines were selected for use in subsequent serological tests.

\section{Heterologous serological tests (feeding trials):}

The experiments cited below was conducted separately for each predator, using insect colony maintained in the rearing lab (LACRI) in Embrapa Maize and Sorghum. To perform the tests, adult abdomen(D. luteipes, E. annulipes) orlarva(C.externa, O. v-nigrum) were used, which were ground and used in full, avoiding greater dilution of the material.

\section{Time (hours) for detecting the type of food consumed after the predator feeding}

To evaluate the time prey eaten by the predator could still be detected serologically, 10 individuals of each were used, D. luteipes, E. annulipes, O. v-nigrum,
C. externa. Initially these predators were kept without food for $24 \mathrm{~h}$. After this period D. luteipes and $E$. annulipes were fed on a seven days old $S$. frugiperda caterpillar. C. externa and $O$. v-nigrum larvae were fed on four-day-old $S$. frugiperda caterpillars. Twentyfour, 48 and 96 hours after feeding the predators were tested against the homologous antiserum. The same experiment was conducted separately for $H$. armigera, $H$. zea and $R$. maidis.

\section{Test sensitivity for different prey species eaten by predatory insects.}

To determine the minimum number of prey ingested by the predator that could still be detected by serology, 10 individuals of each predator were kept without food for $24 \mathrm{~h}$. After this period they received as food, one, two, three or four larvae of $S$. frugiperda. After feeding, the insects were tested against homologous antiserum. The same experiment was conducted separately for $H$. armigera, $H$. zea and $R$. maidis.

\section{Using antiserum to detect the predation of eggs of Lepidoptera pests of corn.}

Ten specimens of each predators fed on 50 eggs of $S$. frugiperda, $H$. armigera and $H$. zea, after a period of 24 hours without food. After complete consumption of eggs, the test proceeded with homologous antiserum. Eggs of Anagasta kuehniella (Zeller, 1879) (Lepidoptera: Pyralidae) were tested to observe possible cross-reactions.

\section{Specificity:}

Serological testing of each antiserum with 
heterologous in reactions using the corresponding macerated (S. frugiperda, H. armigera, $H$. zea and $R$. maidis) were performed to assess the specificity of the antisera, sincethesimilarityofthespeciesusedasantigens allows emergence of cross-reaction, i.e. antiserum obtained for an antigen can react with a different antigen.

\section{Predators confined in cages with ad libitum feeding 24 hours.}

Forty specimen of $D$. luteipes without food for 24 hours, were placed in acrylic cages $(25 \times 25 \times 25 \mathrm{~cm})$, received as food (ad libitum), $S$. frugiperda, $H$. armigera, $H$. zea eggs or nymphs and adults of $R$. maidis for the same period of 24 hours. After this period, the insects were evaluated with different antisera. Similar tests were conducted separately for $E$. annulipes, C. externa and O. v-nigrum. The data were submitted to analysis of variance and treatment means were compared by the Scott \& Knott test at 5\% (Scott \& Knott, 1974), using the Sisvar program (Ferreira, 2007).

\section{Serological tests using predators from the field.}

Field tests were performed with predators manually collected in organic maize area (cultivar BRS1030) at Embrapa Maize and Sorghum Research Center. After capturing the insects they were taken to the laboratory, identified and stored in a freezer at -2 ${ }^{\circ} \mathrm{C}$, to be later used against specific antisera pest $S$. frugiperda, $H$. armigera, $H$. zea and $R$. maidis.

\section{Results and discussion}

\section{Homologous serological tests (feeding trials)}

With only one inoculation of antigens in rabbits, lines of precipitation were observed in serological responses seven days after the immunization process. Homologous serological tests showed positive reactions from $7^{\text {a }}$ to $30^{\text {a }}$ drawing blood. $H$. armigera showed positive reactions from one to four lines of precipitation. The antisera that showed higher title were AsHa 18 ${ }^{\mathrm{a}}$, AsHa 19 ${ }^{\mathrm{a}}$, AsHa $21^{\mathrm{a}}$ and $\mathrm{AsHa} 22^{\mathrm{a}}$.

For $H$. zea, the antisera that showed the highest titers were $\mathrm{AsHz} 19^{\mathrm{a}}, \mathrm{AsHz} 20^{\mathrm{a}}$ and $\mathrm{AsHz} 21^{\mathrm{a}}$, where the precipitation lines also varied from one to four. The precipitation lines varied from one to two and the antisera of major titles were AsSf $14^{\text {a }}$ to AsSf $21^{\text {a }}$ for $S$. frugiperda. Differing from the other, the antiserum of corn aphid showed only a line of precipitation. The antisera were able to react positively to its counterpart antigen in all their development stages (eggs, larvae and pupae), but no difference was observed in the number of precipitation lines.

The speed at the time of Serologic responses positive reactions demonstrated the effectiveness of the immunization process by means of inoculations of lymph node. Oliveira (1975) and Sousa-Silva (1988) observed similar response times in their work. Mollet \& Armbrust (1977) immunized rabbits with intramuscular and intravenous injections of antigen obtained for Hypera postica (Coleoptera: Curculionidae) and the positive results were only observed40daysafterthefirstinoculationinguineapigs.

Cassaro-Silva et al. (2001) and Costa et al. (2009) observed positive responses for serological reactions after two weeks using inoculations via lymph node to obtain specific antisera to Orphulella punctata (De Geer, 1773) (Orthoptera: Acrididae) and Ascia monuste orseis (Latreille, 1819) (Lepidoptera: Pieridae), respectively.

In this work, from the four antisera produced three (AsHa AsHz and AsSf) showed maximum titer 
of $1 / 32$, i.e., the test is able to detect the prey inside the intestine of the predator diluted to 32 times. On the other hand, to corn aphid (AsRm) the antiserum titer was 1/128 (Figure 1).

According to Dempster (1960), the number of inoculations carried out in rabbit and the antigenic power of the injected protein can take direct action in respect of the antiserum. Antisera with high titers can lead to the emergence of cross-reactions. Sousa-Silva (1988) to characterize Deois flavopicta (Stall, 1954) (Homoptera: Cercopidae) predators used insect eggs at different stages of development as antigens for the production of specific antisera. Even in the reactions with the lowest title antiserum (1/4) was possible to characterize the pest predators.

Santos Neto et al. (2010) obtained an antiserum for $S$. frugiperda eggs with title $1 / 8$, enough to recognize the caterpillar predators. Titova (1970) obtained an antiserum against Eurigaster integriceps Put (Heteroptera: Scutelleridae) with a titer of 1 / 10,000 after several antigen inoculations in rabbit. Nevertheless, this also led to a loss of specificity of the antiserum.

In this study, only the abdomens of adult predators were used to avoid further dilution of the material.
Through the serological tests, positive reactions occurred at 24, 48 and 96 hours after feeding predators. Specimens of D. luteipes, E. annulipes, $C$. externa that were fed only with one individual from each pest $(S$. frugiperda, $H$. armigera, $H$. zea) had one to two lines of precipitation, showing that it was possible identifications up to the maximum tested hours (96 hours) after ingestion of prey. O. v-nigrum gave positive reactions 48 hours after ingestion of prey. When the predator fed up with the corn aphid ( $R$. maidis) serological tests were positive until 96 hours after the predator feeding.

Regarding the number of prey, the test has sensitivity to react positively, with a clear line of precipitation after ingestion of only a single larva $(S$. frugiperda, H. zea or $H$. armigera). The number of precipitin lines was not different for the predators fed on one to four caterpillars; however, with the increase of the numberof insect prey the lines were stronger and sharper.

The detection of an insect within the gut of a predator depends on factors like the size of the prey and predator, time after eating, feeding strategy (suction against chewing), abundance of prey, and the test sensitivity (Luck et al., 1988). In serology, difference in processing speed of prey by the predator

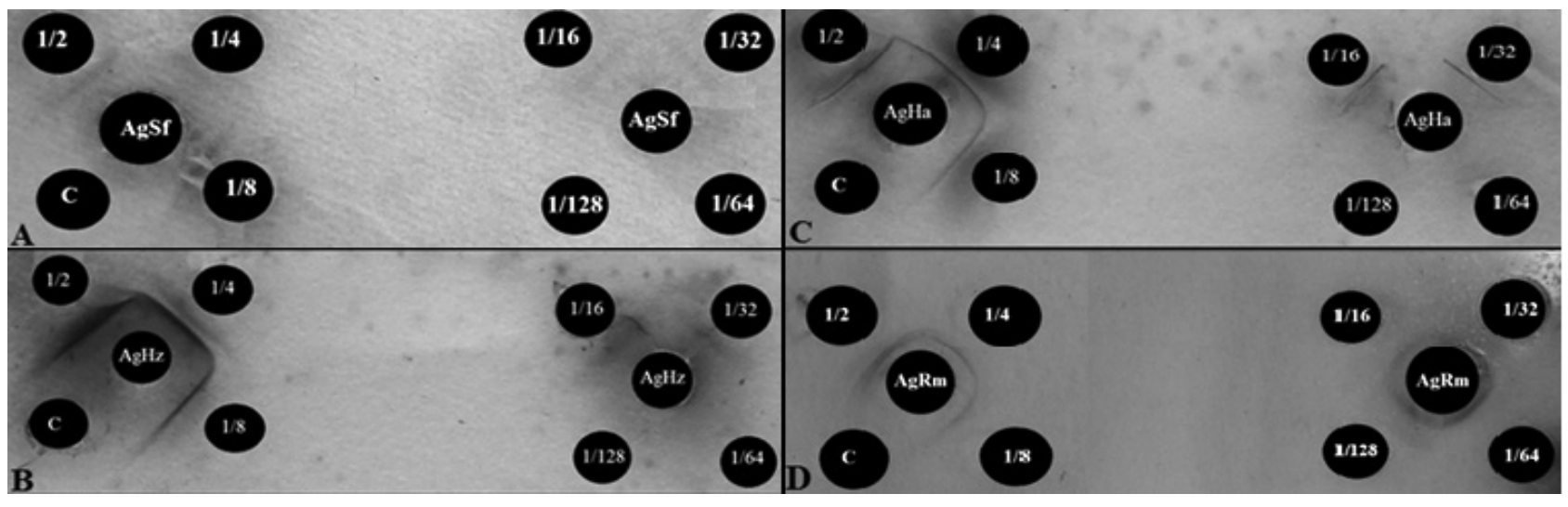

Figure 1. Reaction double diffusion in agar showing the number of precipitin lines observed in the titration of antisera tests: (A) S. frugiperda; (B) H. zea; (C) H. armigera and (D) R. maidis. The arrows in the figures indicate the precipitation lines formed by the positive reactions. 
should be taken into account. The freezing of predators can affect the positive results of serological reactions. The tests should be carried out preferably immediately after taking the predator. When this is not possible, to prevent the continuation of the digestive process and preserve the protein characteristics of the

With antiserum produced, it was also possible to detect the predation of eggs of the pestsstudied in this work. The predators $D$. luteipes, E. annulipes, C. externa and O. v-nigrum individually fed on 50 eggs of $S$. frugiperda, $H$. zea or H. armigera had positive results in homologous reactions demonstrating the specificity of the antiserum. Santos Neto et al. (2010) using antisera obtained from macerated S. frugiperda eggs identified Lagria villosa
(Coleoptera: Lagriidae) and a species of Lygaeidae (Hemiptera) as potential predators of $S$. frugiperda eggs.

\section{Heterologous serologic tests}

Serological tests with each of the antisera AsSf (S. frugiperda), AsHa (H. armigera), $\mathrm{AsHz}(H . z e a)$ and $\operatorname{AsRm}(R$. maidis) in cross-react with the antigens $\mathrm{AgSf}, \mathrm{AgHa}, \mathrm{AgHz}$ and AgRm were positive, showing lack of specificity. The antiserum of corn aphid $(R$. maidis) had positive reaction with the antigens $S$. frugiperda, $H$. armigera and $H$. zea, but the antisera of the caterpillars did not detect the corn aphid antigen. Given the results, we neutralized contaminant fractions responsible for the lack of specific antisera, adding rates

Table 1. Absorption tests of antisera $S$. frugiperda (AsSf), H. armigera (AsHa), H. zea (AsHz) and R. maidis $(\mathrm{AsRm})$ and its reactions with homologous and heterologous antigens. Acronyms $=$ positive reactions $(+)$ and negative reactions (-).

\begin{tabular}{|c|c|c|c|c|c|c|c|c|c|}
\hline \multirow{2}{*}{ Antiserum } & \multicolumn{4}{|c|}{ Antigens } & \multirow{2}{*}{ Antiserum } & \multicolumn{4}{|c|}{ Antigens } \\
\hline & $\mathrm{AgSf}$ & $\mathrm{AgHz}$ & $\mathrm{AgHa}$ & $\mathrm{AgRm}$ & & $\mathrm{AgSf}$ & $\mathrm{AgHz}$ & $\mathrm{AgHa}$ & $\mathrm{AgRm}$ \\
\hline $\mathrm{AsSf}-0.5(\mathrm{AgHz})$ & + & + & + & - & $\mathrm{AsHa}-0.5(\mathrm{AgHz})$ & - & + & + & - \\
\hline $\mathrm{AsSf}-1.0(\mathrm{AgHz})$ & + & + & + & - & $\mathrm{AsHa}-1.0(\mathrm{AgHz})$ & - & + & + & - \\
\hline $\mathrm{AsSf}-1.5(\mathrm{AgHz})$ & + & - & + & - & $\mathrm{AsHa}-1.5(\mathrm{AgHz})$ & - & - & + & - \\
\hline $\mathrm{AsSf}-2.0(\mathrm{AgHz})$ & - & - & - & - & $\mathrm{AsHa}-2.0(\mathrm{AgHz})$ & - & - & - & - \\
\hline $\mathrm{AsSf}-0.5(\mathrm{AgHa})$ & + & + & + & - & $\mathrm{AsHa}-0.5(\mathrm{AgSf})$ & + & + & + & - \\
\hline $\mathrm{AsSf}-1.0(\mathrm{AgHa})$ & + & + & + & - & $\mathrm{AsHa}-1.0(\mathrm{AgSf})$ & + & + & + & - \\
\hline $\mathrm{AsSf}-1.5(\mathrm{AgHa})$ & + & - & - & - & $\mathrm{AsHa}-1.5$ (AgSf) & - & + & + & - \\
\hline $\mathrm{AsSf}-2.0(\mathrm{AgHa})$ & - & - & - & - & $\mathrm{AsHa}-2.0(\mathrm{AgSf})$ & - & - & + & - \\
\hline \multirow{2}{*}{ Antiserum } & \multicolumn{4}{|c|}{ Antigens } & \multirow{2}{*}{ Antiserum } & \multicolumn{3}{|c|}{ Antigens } & \\
\hline & $\mathrm{AgSf}$ & $\mathrm{AgHz}$ & $\mathrm{AgHa}$ & $\mathrm{AgRm}$ & & $\mathrm{AgSf}$ & $\mathrm{AgHz}$ & $\mathrm{AgHa}$ & $\mathrm{AgRm}$ \\
\hline $\mathrm{AsHz}-0.5(\mathrm{AgHa})$ & - & + & + & - & AsRm - $0.5(\mathrm{AgSf})$ & + & - & - & + \\
\hline $\mathrm{AsHz}-1.0(\mathrm{AgHa})$ & + & + & - & - & $\mathrm{AsRm}-0.5(\mathrm{AgHa})$ & - & + & + & + \\
\hline $\mathrm{AsHz}-1.5(\mathrm{AgHa})$ & + & - & + & - & $\mathrm{AsRm}-0.5(\mathrm{AgHz})$ & - & + & + & + \\
\hline $\mathrm{AsHz}-2.0(\mathrm{AgHa})$ & - & - & - & - & & & & & \\
\hline $\mathrm{AsHz}-0.5(\mathrm{AgSf})$ & + & + & + & - & & & & & \\
\hline $\mathrm{AsHz}-1.0(\mathrm{AgSf})$ & + & - & + & - & $\mathrm{AsRm}-0.5(\mathrm{AgSf}+\mathrm{AgHa})$ & - & - & - & + \\
\hline $\mathrm{AsHz}-1.5(\mathrm{AgSf})$ & + & - & + & - & $\mathrm{AsRm}-0.5(\mathrm{AgSf}+\mathrm{AgHz})$ & - & + & - & + \\
\hline AsH z- 2.0 (AgSf) & - & + & - & - & AsRm- $0.5(\mathrm{AgHa}+\mathrm{AgHz})$ & + & - & - & + \\
\hline
\end{tabular}


of non-homologous antigens in different proportions (Table 1).

Changes in the specificity of the antisera were observed after combining a part Sf antiserum with 1.5 part of the $\mathrm{Ha}$ antigen $(1 \mathrm{AsSf} / 1.5 \mathrm{AgHa})$. This combination resulted in a specific antiserum Agha. Combination of a part of the antiserum Ha to two parts of $\mathrm{Sf}$ antigen (1 $\mathrm{AsHa} / 2.0 \mathrm{AgSf})$ resulted in a specific antiserum $\mathrm{AgHz}$. A part of the antiserum $\mathrm{Hz}$ to two parts of Sf antigen (1AsHz-2.0AgSf) resulted in a specific antiserum to the antigen Hz; Finally, a part of the antiserum plus $0.5 \mathrm{Rm}$ of the antigens and $\mathrm{Ha} \mathrm{Sf}$ $(\mathrm{Sf}+\mathrm{AsRm} / 0.5 \mathrm{AgHa})$ resulted in a specific antiserum AgRm (Figure 2). For the desired specificity, the antisera reacted for 24 hours in the refrigerator (10 $\left.{ }^{\circ} \mathrm{C}\right)$ before being transferred to the freezer $\left(-2{ }^{\circ} \mathrm{C}\right)$.

The initial lack of specific antisera may be attributed to the similarities of the proteins used. The three caterpillars studied belong to the same family Noctuidae, two of the same genus $(H$. armigera and H. zea). The non-specificity of the aphid can also be explained by the similarity of proteins between aphid and caterpillars. The proteins, which generated the AsRm, are also present in the caterpillar. However, it is also true that each species has a characteristic protein, like their identity. This characteristic protein may not be as antigen as one believes and the immune system of the rabbit did not respond to its presence, at least by the amount of inoculations used. As demonstrated by several authors, if we increase the inoculations, we further decrease the specificity of the antiserum.

To validate these results before the catch in cornfield, a food testing with predators was accomplished in the laboratory. Forty adult $D$. luteipes without food for 24 hours and confined in acrylic cage fed after that period (ad libitum) on eggs of $S$. frugiperda, $H$. armigera, $H$. zea or $\mathrm{R}$. maidis nymphs per 24 hours. The same test was also conducted separately for E. annulipes O. v-nigrum and $C$. externa. After this feeding period, macerated predators using sterile saline solution were placed to react with each antiserum produced. The percentages of positive reactions by the serological tests showed predation rate for $D$. luteipes, $H$. axyridis, $C$. externa and E. annulipes (Table 2).

Doru luteipes showed positive reactions to $R$. maidis (75\%), H. zea and $H$. armigera $(8.3 \%)$ and $S$. frugiperda (4.2\%). The species O. v-nigrum fed only on aphid $R$. maidis showed $100 \%$ positive reactions to this prey. For $C$. externa, reactions were positive for $R$. maidis $(66.67 \%), H$. zea $(20.8 \%), H$. armigera (4.3\%) and S. frugiperda (4.17\%). For E. annulipes predation rate was $37.5 \%$ for S. frugiperda, 29.2\% for $R$. maidis and 16.7 and $12.5 \%$ for $H$. zea and $H$. armigera, respectively. According to these results, the earwigs and the green lacewing although feeding on all preys had food preference by the aphid $R$. maidis.

For the tests with field insects, sampling carried out in organic corn production area (cultivar BRS1030), from 1050 obtained with entomological net, 741 were predators who, after frozen to preserve the most of your stomach and macerated content with saline $(0.85 \%)$ were put to react with specific antisera by double diffusion in agar (Figure 3 ).

The results (Table 3) showed that from the 741 analyzed predators, 477 (64.37\%) were positive with at least one of the four antisera tested. From the collected predators, the earwigs $D$. luteipes with 538 individuals, 312 had positive reactions (58\%), where $26.7 \%$ was with $R$. maidis and $32.03 \%$ with $S$. frugiperda. The two individuals of E. annulipes, showed $100 \%$ positive reactions to $R$. maidis. $D$. luteipes is one of the most important natural enemies 


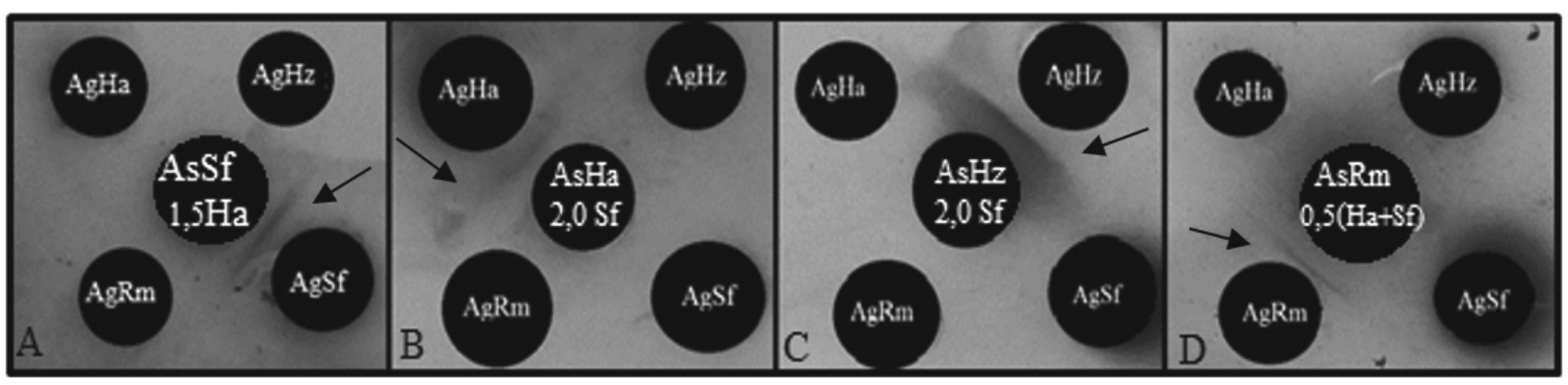

Figure 2. Reaction double diffusion in agar showing precipitation lines after heterologous reactions with specific antisera. Positive reaction with its antigen: (A) S. frugiperda, (B) H. armigera, (C) H. zea, (D) $R$. maidis. The arrows in the figures indicate the precipitation lines formed by the positive reactions.

Table 2. Percentage of positive reactions by serological tests (Mean $\pm \mathrm{SE}$ ) of predators in cages feeding on $R$. maidis, S. frugiperda, H. zea and H. armigera, for 24 hours.

\begin{tabular}{llccc}
\hline \multirow{2}{*}{\multicolumn{1}{c}{ Predators }} & \multicolumn{3}{c}{ Positive Reaction $(\%)^{1}$} \\
\cline { 2 - 5 } & \multicolumn{1}{c}{ R. maidis } & S. frugiperda & H. zea & H. armigera \\
\hline Doru luteipes & $75 \pm 0.09 \mathrm{Ba}$ & $8.3 \pm 0.05 \mathrm{Bb}$ & $4.2 \pm 0.04 \mathrm{Ab}$ & $8.3 \pm 0.05 \mathrm{Ab}$ \\
Olla v-nigrum & $100 \pm 0.0 \mathrm{Aa}$ & $0.0 \pm 0.0 \mathrm{Bb}$ & $0.0 \pm 0.0 \mathrm{Ab}$ & $0.0 \pm 0.0 \mathrm{Ab}$ \\
Chrysoperla externa & $66.67 \pm 0.09 \mathrm{Ba}$ & $4.17 \pm 0.04 \mathrm{Bc}$ & $20.8 \pm 0.08 \mathrm{Ab}$ & $8.3 \pm 0.05 \mathrm{Ac}$ \\
Euborellia annulipes & $29.2 \pm 0.09 \mathrm{Ca}$ & $37.5 \pm 0.10 \mathrm{Aa}$ & $16.7 \pm 0.07 \mathrm{Ab}$ & $12.5 \pm 0.06 \mathrm{Ab}$ \\
\hline
\end{tabular}
$\mathrm{CV}(\%)$

12,51

${ }^{1}$ Mean followed by the same letter, uppercase in columns or lowercase in lines for each positive reaction, do not differ by the ScottKnott test (Scott \& Knott, 1974) at 5\% significance level.

in suppressing pests in corn, as adults and nymphs are common in field and can consume daily eggs and larvae of both $S$. frugiperda and $H$. zea (Cruz et al., 1995; Cruz \& Oliveira, 1997; Reis et al., 1988; Cruz, 2007). The importance of Dermaptera as biological control agents has been well documented in the scientific literature (Silva et al., 2009; Bastos \& Torres, 2006; Saran et al., 2007).

Ladybugs species were $H$. axyridis, $E$. connexa, O. v-nigrum and C. sanguinea. Of the four species, only $O$. v-nigrum showed the highest rate of positive results for $S$. frugiperda $(44.4 \%)$. E. connexa and $H$. axyridis, with 82.75 and $79.43 \%$, respectively, reacted positively to a greater percentage for $R$. maidis. Unlike other ladybugs, $C$. sanguinea reacted only with $R$. maidis.

Factors such as the availability of prey in the environment, the size of both the prey and the predator and palatability of prey, may influence the choice of prey. According to Giorgi et al. (2009), some ladybugs species exhibit clearly food preferences and food selection related to the availability of prey in the environment.

C. externa, Zelus sp and carabids also reacted positively only with the antiserum $R$. maidis, with percentages of $100,83.3$ and $50 \%$, respectively. There was no reaction with antisera involving $H$. armigera and $H$. zea. It may be because of the absence of these 


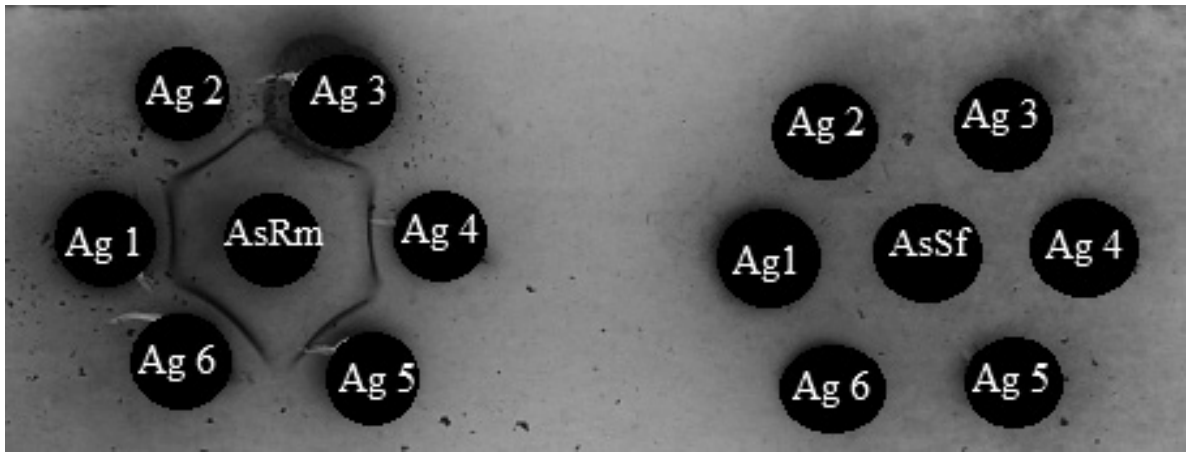

Figure 3. Reactions of double diffusion in agar showing lines of precipitation after the reactions of six antigens (collected predators in the field) with specific antisera $R$. maidis and $S$. frugiperda. The arrows in the figures indicate the precipitation lines formed by the positive reactions.

Table 3. Results of serological tests (Mean \pm SE) to predators collected in organic corn crop, cultivar BRS1030.

\begin{tabular}{lcccccc}
\multirow{2}{*}{ Predators } & $\mathrm{N}$ & $\begin{array}{c}\text { Positive } \\
\text { reaction }\end{array}$ & \multicolumn{4}{c}{ Percentage of positive reactions } \\
\cline { 6 - 7 } & & & R. maidis & S. frugiperda & H. zea & H. armigera \\
\hline Doru luteipes & 538 & 312 & $26.07 \pm 0.01$ & $32.03 \pm 0.02$ & $0.0 \pm 0.0$ & $0.0 \pm 0.0$ \\
Euborellia annulipes & 2 & 2 & $100 \pm 0.00$ & $0.0 \pm 0.0$ & $0.0 \pm 0.0$ & $0.0 \pm 0.0$ \\
Harmonia axyridis & 141 & 118 & $79.43 \pm 0.03$ & $4.37 \pm 0.01$ & $0.0 \pm 0.0$ & $0.0 \pm 0.0$ \\
Eriopis connexa & 29 & 28 & $82.75 \pm 0.07$ & $13.79 \pm 0.06$ & $0.0 \pm 0.0$ & $0.0 \pm 0.0$ \\
Olla v-nigrum & 9 & 5 & $11.11 \pm 0.13$ & $44.4 \pm 0.21$ & $0.0 \pm 0.0$ & $0.0 \pm 0.0$ \\
Cycloneda sanguinea & 4 & 1 & $25.0 \pm 0.20$ & $0.0 \pm 0.0$ & $0.0 \pm 0.0$ & $0.0 \pm 0.0$ \\
Chrysoperla externa & 4 & 4 & $100 \pm 0.00$ & $0.0 \pm 0.0$ & $0.0 \pm 0.0$ & $0.0 \pm 0.0$ \\
Carabidae & 6 & 2 & $33.33 \pm 0.20$ & $0.0 \pm 0.0$ & $0.0 \pm 0.0$ & $0.0 \pm 0.0$ \\
Zellus sp & 8 & 5 & $83.33 \pm 0.18$ & $0.0 \pm 0.0$ & $0.0 \pm 0.0$ & $0.0 \pm 0.0$ \\
\hline \multicolumn{1}{c}{ Total } & 741 & 477 & - & - & - & - \\
\hline
\end{tabular}

two pests in maize at the time the samples were taken. In the laboratory, there was a positive reaction from predators with these two pests confirming the specificity of the antiserum produced.

Silva et al. (2009) studied the predatory capacity and functional response of $C$. externa larvae fed with different densities of nymphs (second and third instar) of
R. maidis. Consumption increased in proportion to the larval development stage, being higher in the third instar, with 279.1 aphids, representing approximately $82.0 \%$ of total consumption. Bastos \& Torres (2006) presented data confirming that lacewings preferentially prey on aphids and throughout their larval stage can consume 100-600 aphids even being able to prey on many insects. 
In this work, $C$. externa showed a higher percentage of positive results in serological reactions with antiserum $R$. maidis (AsRm), confirming the preference of this predator by aphid over caterpillars

Field work on the feeding preference of predatory insects are extremely important for a better understanding of the availability of food in its natural environment, as well as other related factors such as population dynamics of the pest species and the diversity of predators, providing important information for the choice of species that could be used in biological control programs.

It is worth noting that studies involving serology are to qualify the predator-prey relationship. Estimate the amount of prey consumed, for example, is not possible without taking into account the temperature, rate digestion of the prey and the influence of time after feeding the predator (McIver, 1981). Probably this set of factors may have affected the results of the serological reactions to the material collected in the field, contributing to false negative results due to the decrease of the antigen in the gut of the predator to the point of not being detected by the antiserum (Santos et al., 2009). However, negative results may not mean that the predator did not consume the prey, but may be the result of the effect of any of the aforementioned factors. Although quantification is affected by several factors, it was observed in this study that there is a food preference by $R$. maidis and $S$. frugiperda, observed in laboratory and field tests, confirming the importance of these studies for choosing effective predators as candidates for use in biological control programs.

\section{Conclusions}

It is possible to obtain antiserum specific for $S$. frugiperda, $H$. armigera, $H$. zea and $R$. maidis.
Positive serological reactions are detected up to 96 hours of consumption of prey by the predator

Regarding the number of prey, the test has sensitivity to react positively to ingestion of a first instar caterpillar (S. frugiperda, H. zea or H. armigera) and an aphid ( $R$. maidis).

Serological tests in field showed the feeding preference of D. luteipes and $O$. v-nigrum by $S$. frugiperda and E. annulipes and C. externa by aphid R. maidis.

The Serology, besides being a simple and low-cost tool, is highly efficient in the study for the qualification of predators.

\section{Acknowledgment}

The National Council for Scientific and Technological Development (CNPq) for scholarships

\section{References}

BASTOS, C. S.; TORRES, J. B. Controle biológico e o manejo de pragas do algodoeiro. 2. ed. Campina Grande: Embrapa Algodão, 2006. 63 p. (Embrapa Algodão. Circular Técnica, 72).

BUENO, V. H. P. (Ed.). Controle biológico de pragas: produção massal e controle de qualidade. Lavras: UFLA, 2000. 207 p.

CASSARO-SILVA, M.; SERRÃO, J. E.; SOUSA-SILVA, C. R.; PACHECO, J. M. Identificação de predadores de Orphulella punctata (de Geer) (Orthoptera: Acrididae) através da serologia. Revista Brasileira de Zoologia, São Paulo, v. 18, n. 1, p. 75-79, 2001.

DOI: $10.1590 / \mathrm{S} 0101-81752001000100007$.

CONAB. Companhia Nacional de Abastecimento. Acompanhamento da safra brasileira de grãos: décimo levantamento: julho/2015. Brasília, DF, 2015. Available at: 
$<$ http://www.conab.gov.br>. Accessed on: 16 July 2015.

COSTA, F.; LOFFREDO, A. P.; ONODY, H. C.; SOUSASILVA, C. R. Utilização da serologia na identificação de Ascia monuste orseis (Latreille,1819) (Lepidoptera: Pieridae). Acta Scientiarum. Biological Sciences, Maringá, v. 31, n. 2, p. 149-151, 2009.

DOI: $10.4025 /$ actascibiolsci.v31i2.515.

CRUZ, I. Avanços e desafios no controle biológico com predadores e parasitoides na cultura do milho. In: SEMINÁRIO NACIONAL [DE] MILHO SAFRINHA, 13., 2015, Maringá. Anais... Maringá: Universidade Estadual de Maringá, 2015. p. 647-662.

CRUZ, I. (Ed.). Manual de identificação de pragas do milho e de seus principais agentes de controle biológico. Brasília, DF: Embrapa Informação Tecnológica; Sete Lagoas: Embrapa Milho e Sorgo, 2008a. 192 p.

CRUZ, I. Controle biológico de pragas na cultura de milho destinado à produção de conservas (minimilho). In: PEREIRA FILHO, I. A. (Ed.). Minimilho: cultivo e processamento. Sete Lagoas: Embrapa Milho e Sorgo, 2008b. p. 143-187.

CRUZ, I. Controle biológico de pragas de milho. In: CRUZ, J. C.; KARAM, D.; MONTEIRO, M. A. R.; MAGAlHÃes, P. C. (Ed.). A cultura do milho. Sete Lagoas: Embrapa Milho e Sorgo, 2008c. cap. 13, p. 363-417.

CRUZ, I. Controle biológico de pragas na cultura de milho para produção de conservas (Minimilho), por meio de parasitóides e predadores. Sete Lagoas: Embrapa Milho e Sorgo,2007.16p.(EmbrapaMilhoeSorgo.CircularTécnica,91).

CRUZ, I. Controle biológico de pragas no cultivo do milho verde. In: PEREIRA FILHO, I. A. (Ed.). O cultivo do milho verde. Sete Lagoas: Embrapa Milho e Sorgo, 2002. cap. 9, p. 157-178.

CRUZ, I. Insetos benéficos. In: CRUZ, I. (Ed.). Manual de identificação de pragas do milho e de seus principais agentes de controle biológico. Brasília, DF: Embrapa Informação Tecnológica; Sete Lagoas: Embrapa Milho e
Sorgo, 2008d. cap. 2, p. 121-192.

CRUZ, I. Métodos de criação de agentes entomófagos de Spodoptera frugiperda. In: BUENO, V. H. P. (Ed.). Controle biológico de pragas: produção massal e controle de qualidade. 2. ed. rev. ampl. Lavras: UFLA, 2009. p. 237-275.

CRUZ, I.; ALVARENGA, C. D.; FIGUEIREDO, P. E. F. Biologia de Doru luteipes (Scudder) e sua capacidade predatória de ovos de Helicoverpa zea (Boddie). Anais da Sociedade Entomológica do Brasil, Londrina, v. 24, n. 2, p. 273-278, 1995.

CRUZ, I.; FIGUEIREDO, M. L. C.; SILVA, R. B.; DEL SARTO, M.L.; PENTEADO-DIAS, A. M. Monitoramento de parasitoides de lagartas de Spodoptera frugiperda (J. E. Smith) (Lepidoptera: Noctuidae) em municípios de Minas Gerais, Brasil. Sete Lagoas: Embrapa Milho e Sorgo, 2009. 29 p. (Embrapa Milho e Sorgo. Documentos, 92).

CRUZ, I.; LOPES, S. R.; FIGUEIREDO, M. de L.; VIANA, P. A.; MENDES, S. M. Controle biológico de pragas do milho-doce. In: PEREIRA FILHO, I. A.; TEIXEIRA, F. F. (Ed.). O cultivo do milho-doce. Brasília, DF: Embrapa, 2016. cap. 11, p. 205-224.

CRUZ, I.; OLIVEIRA, A. C. Flutuação populacional do predador Doru luteipes Scudder em plantas de milho. Pesquisa Agropecuária Brasileira, Brasília, DF, v. 32, p. 363-368, abr. 1997.

CRUZ, I.; VIANA, P. A.; WAQUIL, J. M. Pragas da fase vegetativa e reprodutiva. In: CRUZ, J. C. (Ed.). Cultivo do milho. 3. ed. Sete Lagoas: Embrapa Milho e Sorgo, 2007. (Embrapa Milho e Sorgo. Sistema de produção, 1).

CRUZ, I.; MENDES, S. M.; VIANA, P. A. Importância econômica e manejo de insetos sugadores associados à parte aérea de plantas de milho Bt. Sete Lagoas: Embrapa Milho e Sorgo, 2012. 14 p. (Embrapa Milho e Sorgo. Circular Técnica, 175).

CZEPAK, C.; ALBERNAZ, K. C.; VIVAN, L. M.; GUimarÃes, H. O.; CARVAlHAis, T. Primeiro 
registro de ocorrência de Helicoverpa armigera (Hübner) (Lepidoptera: Noctuidae) no Brasil. Pesquisa Agropecuária Tropical, Goiânia, v. 43, p. 110-113, 2013. DOI: $10.1590 /$ S1983-40632013000100015.

DEMPSTER, J. P. A quantitative study of the predators on the eggs and larvae of the broom beatle Phytodecta olivacea Forster, using the precipitin test. Journal of Animal Ecology, Oxford, v. 29, n. 1, p. 149-167, 1960. DOI: $10.2307 / 2275$.

FERREIRA, D. F. SISVAR: programa estatístico: versão 5.0. Lavras: UFLA, 2007. Software.

FIGUEIREDO, M. L. C.; MARTINS-DIAS, A. M. P.; CRUZ, I. Relação entre a lagarta-do-cartucho e seus agentes de controle biológico natural na produção de milho. Pesquisa Agropecuária Brasileira, Brasília, DF, v. 41, n. 12, p. 1693-1698, 2006. DOI: 10.1590/S0100-204X2006001200002.

GIORGI, J. A.; VANDENBERG, N. J.; MCHUNG, J. V.; FORRESTER, J. A.; SLIPINSKI, A.; MILLER, K. B.; SHAPIRO, L. R.; WHITING, M. F. The evolution of food preferences in Coccinellidae. Biological Control, Orlando, v. 51, n. 2, p. 215-231, 2009.

DOI: 10.1016/j.biocontrol.2009.05.019.

LUCK, R. F.; SHEPARD, B M.; KENMORE, P. E. Experimental methods for evaluating arthropod natural enemies. Annual Review of Entomology, Stanford, v. 33, p. 367-391, 1988.

McIVER, J. D. An examination of the utility of the precipitin test for evaluation of arthropod predator-prey relationships. The Canadian Entomologist, Ottawa, v. 113, n. 3, p. 213-222, 1981. DOI: 10.4039/Ent113213-3.

MOLLET, J. A.; ARMBRUST, E. J. Age specific serological identification of adult stages of alfalfa weevil, Hypera postica. Annals of the Entomological Society of America, College Park, v. 71, n. 2, p. 207-211, 1977. DOI: 10.1093/aesa/71.2.207.

OLIVEIRA, A. R. Considerações sobre antissoros obtidos pela técnica de injeção de antígeno no linfonódulo. Summa Phytopathologica, Piracicaba, v. 1, p. 61-64, 1975.

PETTERSSON, J. Technical description of a serological method for quantitative predator efficiency studies on Rhopalosiphum padi (L.). Swedish Journal of Agricultural Research, Stockholm, v. 2, p. 65-69, 1972.

REIS, L. L.; OLIVEIRA, L. J.; CRUZ, I. Biologia e potencial de Doru luteipes no controle de Spodoptera frugiperda. Pesquisa Agropecuária Brasileira, Brasília, DF, v. 23, p. 333-342, 1988.

\section{RODRIGUEZ-DEL-BOSQUE, L. A.;}

CANTUALMAGUER, M. A.; REYES-MENDEZ, C. A. Larval competition between Helicoverpa zea and Spodoptera frugiperda (Lepidoptera: Noctuidae) on corn ears in Northern Mexico. Journal of Entomological Science, College Park, v. 47, n. 2, p. 185-187, 2012.

DOI: $10.18474 / 0749-8004-47.2 .185$.

SANTOS, S. A. P.; PEREIRA, J. A.; RODRIGUES, M. C.; TORRES, L. M.; PEREIRA, A. M. N.; NOGUEIRA, A. J. A. Identification of predator-prey relationships between coccinellids and Saissetia oleae (Hemiptera: Coccidae), in olive groves, using an enzyme-linked immunosorbent assay. Journal of Pest Science, v. 82, n. 2, p. 101-108, 2009. DOI: $10.1007 / \mathrm{s} 10340-008-0226-9$.

SANTOS NETO, J. R.; MEZENCIO, J. M. S.; MICHEREFF FILHO, M.; SERRÃO, J. E. Use of serological techniques for determination of Spodoptera frugiperda (J. E. Smith) predators (Lepidoptera: Noctuidae). Neotropical Entomology, Londrina, v. 39, n. 3, p. 420-423, 2010.

DOI: 10.1590/S1519-566X2010000300016.

SARAN, E. D.; THOMAZONI, D.; SERRA, A. P.; DEGRANDE, $P$. Manual dos insetos benéficos do algodoeiro. Campinas: FMC- Química do Brasil, 2007. v. $1,227 \mathrm{p}$.

SCHAAD, N. W.; SULE, S.; VAN VUURDE, J. W. L.; VRUGGINK, H.; ALVAREZ, A. M.; BENEDICT, A. A; 
DE WAEL, L.; VAN LAERE, O. Serology. In: KLEMENT, Z.; RUDOLPH, K.; SANDS, D. C. (Ed.). Methods in phytobacteriology. Budapest: Akadémiai Kiadó, 1990. p. 153-190.

SCOTT, A. J.; KNOTT, M. A. A cluster analyses method for grouping means in the analyses of variance. Biometrics, Washington, v. 30, n. 3, p. 507-512, 1974. DOI: $10.2307 / 2529204$.

SILVA, A. B.; BATISTA, J. L.; BRITO, C. H. Capacidade predatória de Euborellia annulipes (Lucas, 1847) sobre Spodoptera frugiperda (Smith, 1797). Acta Scientiarum Agronomy, Maringá, v. 31, n. 1, p. 7-11, 2009.
DOI: 10.4025/actasciagron.v31i1.6602.

SOUSA-SILVA, C. R.; OLIVEIRA, A. R.; PACHECO, J. M. Diferenciação serológica dos estágios fisiológicos de Deois flavopicta (Stal, 1854) (Homoptera: Cercopidae). Anais da Sociedade Entomológica do Brasil, Jaboticabal, v. 17 , p. $61-65,1988$.

TITOVA, E V. Use of precipitin test in a study of interrelationship between Eurygaster integriceps Put (Hemiptera: Scuteleridae) and predatory arthropods. Entomological Review, Washington, v. 49, n. 2, p. 155-162, 1970. 